\title{
Adsorption of Anionic Dyes on the Biopolymer Chitin
}

\author{
Elisane Longhinotti, Fabíola Pozza, Lígia Furlan, Maria de Nazaré de M. \\ Sanchez, Marilene Klug, Mauro C.M. Laranjeira, and Valfredo T. Fávere**
}

Grupo de Pesquisa em Quitinas e Aplicações Tecnológicas (QUITECH),

Departamento de Química, Universidade Federal de Santa Catarina, C.P. 476,

88040-900 Florianópolis - S.C., Brazil

Received: August 27,1997

\begin{abstract}
A adsorção dos corantes aniônicos alaranjado IV, alaranjado G e alaranjado de xilenol pela quitina foi estudada empregando a isoterma de Langmuir. Os parâmetros de adsorção foram determinados utilizando várias regressões lineares da isoterma. Os resultados revelaram que a capacidade de adsorção é dependente do $\mathrm{pH}$. Em pH ácido, os grupos aminos do polímero estão protonados e a cadeia polimérica está carregada positivamente, predominando a adsorção por troca iônica. Deve ocorrer também em pequena extensão adsorção de van der Walls e por ligações de hidrogênio. Para o alaranjado de xilenol uma relação linear com coeficiente angular de $0,726 \mathrm{~L} \mathrm{mg}^{-1}$ foi encontrada. $\mathrm{O}$ aumento da temperatura diminui a capacidade de adsorção pela quitina, devido ao aumento da etapa de desorção no mecanismo. Os valores de $\Delta \mathrm{H} \mathrm{de}-10,9 \mathrm{~kJ} \mathrm{~mol}^{-1}$ para o alaranjado $\mathrm{G} \mathrm{e}-28,9 \mathrm{~kJ} \mathrm{~mol}^{-1}$ para o alaranjado IV comprovam uma adsorção de natureza física para estes corantes sobre a superfície da quitina.

The adsorption of the anionic dyes orange IV, orange $\mathrm{G}$ and xylenol orange on chitin was studied, employing the Langmuir isotherm. The adsorption parameters were determined utilizing various linear regressions of the isotherm. The results showed that the adsorption capacity is dependent on $\mathrm{pH}$. In acid $\mathrm{pH}$, the polymer amino groups are protonated and the polymer chain is positively charged, with a predominance of adsorption through ion exchange. Van der Waals adsorption, as well as adsorption through hydrogen bonding, is also likely to occur to some extent. For xylenol orange, a linear regression was found, with an angular coefficient of $0.726 \mathrm{~L} \mathrm{mg}^{-1}$. The temperature increase reduces adsorption capacity by chitin, due to the enhancement of the desorption step in the mechanism. $\Delta \mathrm{H}$ values of $-10.9 \mathrm{~kJ} \mathrm{~mol}^{-1}$ for orange $\mathrm{G}$ and $-28.9 \mathrm{~kJ} \mathrm{~mol}^{-1}$ for orange IV prove the physical nature of the adsorption by these dyes on the chitin surface.
\end{abstract}

Keywords: anionic dyes, Langmuir adsorption isotherm, chitin

\section{Introduction}

Chitin is a very common natural polysaccharide, found in marine animals, insects and fungi. This biopolymer consists predominantly of repeated units of $\mathrm{N}$-acetyl- $\beta$-Dglucosamine (Fig. 1a) and will normally contain a small number of $\beta$-D-glucosamine units (Fig. 1b) in a chain ${ }^{1-3}$.

Chitin has been utilized as an adsorbent for a variety of substrates. Yang and Zall ${ }^{4}$ have studied the adsorption of various metallic ions. Giles and Hassan ${ }^{5}$ have investigated the adsorption of ionic species of sulfonated azo dyes and

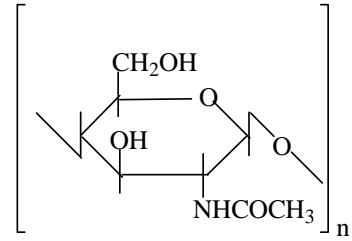

(a)

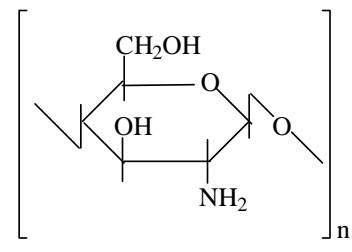

(b)
Figure 1. (a) Structure of N-acetyl- $\beta$ - D-glucosamine unit. (b) Structure of $\beta$-D-glucosamine unit. 
inorganic and organic acids. McKay et al. ${ }^{6}$ have studied in detail the adsorption of blue acid dye 25 , blue acid 158 , mordant yellow 5 and direct red 24 .

The study of adsorption is important for various physico-chemical processes and for an understanding of phenomena such as textile dyeing, clarification and depollution of industrial liquid effluents ${ }^{7,8}$.

For industrial liquid effluents, color is the first indication of water pollution. The industrial dumping of effluents containing dyes not only mars the natural beauty of the rivers, but is extremely toxic to aquatic life, interfering in the transmission of sunlight and thus reducing the action of photosynthesis ${ }^{9}$.

The removal of dyes in the effluents is one of the major problems requiring solution by the textile industries. Some processes have been employed in order to solve this problem, such as adsorption ${ }^{9,10}$, chemical floculation ${ }^{11}$, chemical oxidation $^{12,13}$ and biological techniques ${ }^{14,15}$. Adsorption appears to be a good alternative for the treatment of effluents.

The aim of the present study is to investigate the adsorption of the dyes orange $\mathrm{G}$ (OG), orange IV (OIV) and xylenol orange $(\mathrm{XO})$ by the biopolymer chitin, utilizing Langmuir isotherm to determine the adsorption parameters.

\section{Experimental}

\section{Chitin extraction}

Chitin was extracted from the exoskeleton of shrimp with $\mathrm{NaOH} 1 \mathrm{~mol} \mathrm{~L}^{-1}$ for $24 \mathrm{~h}$. This process was repeated three times with alkaline solution. The material was washed with water until the $\mathrm{pH}$ became neutral and demineralization was then carried out with $\mathrm{HCl} 2 \mathrm{~mol} \mathrm{~L}^{-1}$ at room temperature. The pigments were oxidized with $\mathrm{NaClO} 1 \%$ $\mathrm{w} / \mathrm{v}$ and the material was washed until its $\mathrm{pH}$ was neutral. The material was then dried at $100{ }^{\circ} \mathrm{C}$ for two hours ${ }^{16,17}$ and pulverized at 100 mesh. The degree of deacetylation of the chitin determined by elemental analysis (Perkin Elmer 2400) was $10 \%(\mathrm{w} / \mathrm{w})$.

Dyes

The dyes utilized in the adsorption experiments are illustrated below and were used as commercial salts.

Orange G as supplied by Synth (95\% purity) (Fig. 2).

Orange IV as supplied by Sigma (98\% purity) (Fig. 3).

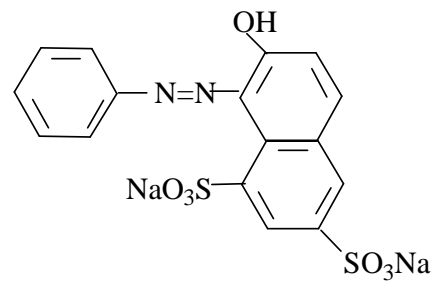

Figure 2. Structure of Orange G (OG).

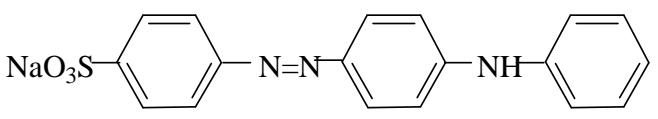

Figure 3. Structure of Orange IV (OIV).

Xylenol Orange as supplied by Vetec ( $90 \%$ purity) (Fig. 4).

\section{Dependence on $\mathrm{pH}$}

Samples of $100 \mathrm{mg}$ of chitin were placed in a conical flask, with $25 \mathrm{~mL}$ of dye solution. The $\mathrm{pH}$ was adjusted to the desired value by the addition of acid or alkaline solution and control of the medium ionic strength was achieved by addition of $\mathrm{NaCl} 0.10 \mathrm{~mol} \mathrm{~L}^{-1}$. The flask was then closed and placed in a bath controlled by a thermostat at $25.0 \pm$ $0.5^{\circ} \mathrm{C}$, for two hours. After the contact period, supernatants were separated from the solid phase by centrifugation, and the concentrations of dyes in solution were determined from the respective analytical curves. The quantity of the dyes adsorbed was determined by the following equation:

$$
\{\mathrm{QD}\}=\frac{\left(\mathrm{C}_{0}-\mathrm{C}_{\mathrm{f}}\right) \mathrm{V}}{\mathrm{W}}
$$

where $\{Q D\}$ is the quantity of dye adsorbed $\left(\mathrm{mg} \mathrm{g}^{-1}\right), \mathrm{C}_{\mathrm{o}}$ is the initial concentration of dye in the solution $\left(\mathrm{mg} \mathrm{mL}^{-1}\right)$, $\mathrm{C}_{\mathrm{f}}$ is the final concentration of dye in the solution ( $\mathrm{mg}$ $\left.\mathrm{mL}^{-1}\right), \mathrm{V}$ is the volume of the solution in milliliters $(\mathrm{mL})$ and $\mathrm{W}$ is the mass of chitin in grams.

\section{Adsorption isotherms}

The adsorption isotherms were obtained by the batch method, employing $100 \mathrm{mg}$ of chitin and $25 \mathrm{~mL}$ of the dye solution at different concentrations. These solutions were buffered at a $\mathrm{pH}$ optimum ( $\mathrm{pH} 4.0)$ for adsorption. These solutions were stirred in mechanical shakers until they reached adsorption equilibrium (60 $\mathrm{min})$. The polymer was separated by centrifugation and the quantity of dye adsorbed was determined by employing a spectrophotometer UV-Vis, Hitachi model U-3000, in the respective $\lambda_{\text {max. }}$ of each dye.<smiles>[R]C(=O)CCN(CCCCCCCC(=O)O)C(=O)O</smiles>

Figure 4. Structure of Xylenol Orange (OX). 


\section{Results and Discussion}

The effect of the different values of $\mathrm{pH}$ on the adsorption of dyes by chitin is represented in Fig. 5. The data indicates that the adsorption capacity of dyes by chitin is dependent on $\mathrm{pH}$. The biopolymer has functional groups $\mathrm{OH}, \mathrm{NHCOCH}_{3}$ and $\mathrm{NH}_{2}$. According to Giles and Hassan ${ }^{5}$, the hydroxyl groups of the polymer are strongly hydrated and are virtually incapable of forming hydrogen bonds with dyes; nevertheless they can adsorb, by the formation of a hydrogen bond, by van der Waals interactions and also by ion exchange with other groups.

Depending on the $\mathrm{pH}$ in the water, the polymers containing the amino groups are neutral $\left(-\mathrm{NH}_{2}\right)$ or cationic $\left(-\mathrm{NH}_{3}+\right)$. At a $\mathrm{pH}$ of higher acidity, these groups are protonated and to maintain neutrality in an aqueous environment, negative counter-ions are adsorbed. These ions are movable and are exchanged by ions from the dyes at appropriate $\mathrm{pH}$. In this case we have a process of ionic exchange in which electrostatic interactions are involved ${ }^{8}$.

The results show a tendency towards greater adsorption for anionic dyes (in the $\mathrm{pH}$ range of 3-4). At a $\mathrm{pH}$ below 2, the anions in the solution compete with the anionic dye, thereby decreasing adsorption. This is also observed in alkaline $\mathrm{pH}$ since the amino groups of the polymer are deprotonated.

The most frequently employed adsorption processes consist of measuring the relation between the concentration of the solution in the solid phase and the concentration of equilibrium in the aqueous phase. The Langmuir adsorption isotherm is the best known model and the one most frequently utilized to determine the adsorption parameters ${ }^{6,718-20}$. The Langmuir expression can be represented by the equation:

$$
\{\mathrm{QD}\}=\frac{\mathrm{C}_{\mathrm{m}} \mathrm{K}[\mathrm{D}]}{1+\mathrm{K}[\mathrm{D}]}
$$

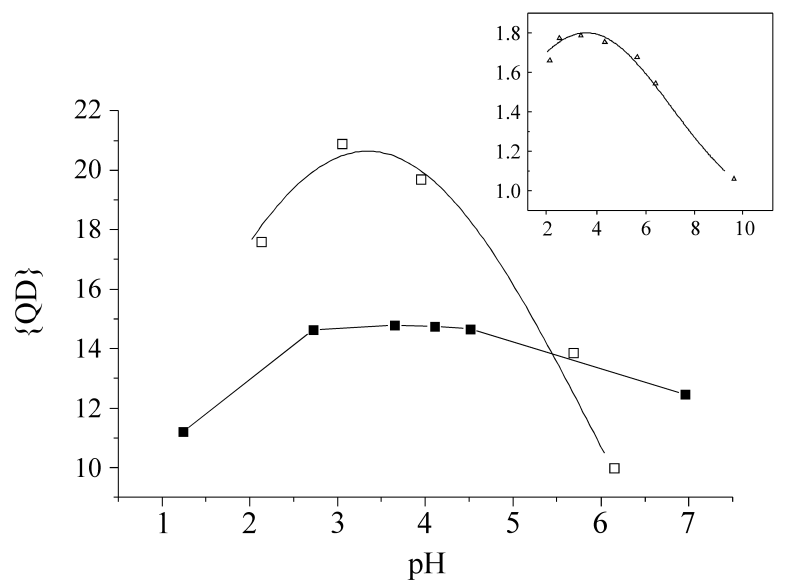

Figure 5. $\mathrm{pH}$ effect on the adsorption of dyes by chitin at $25.0 \pm 0.5^{\circ} \mathrm{C}$. चO $(100 \mathrm{mg} / \mathrm{L})$. $\square \mathrm{OG}(100 \mathrm{mg} / \mathrm{L}) . \Delta$ OIV $(5.0 \mathrm{mg} / \mathrm{L})$. where $\{\mathrm{QD}\}$ is equal to the quantity of dye adsorbed in milligrams per gram of chitin, $\mathrm{C}_{\mathrm{m}}$ is the maximum quantity of dye adsorbed in mg per gram of chitin, $\mathrm{K}$ is the constant of the Langmuir adsorption, and [D] is the dye concentration of the equilibrium in milligrams per liter. Figures 6,7, and 8 show the adsorption curves of the three dyes by chitin.

The experimental data in this work was always interpreted in terms of the Langmuir isotherm. Regarding Langmuir, the quantity adsorbed reaches a near-saturation level when the concentration of equilibrium increases; however, for xylenol orange, a linear relation was observed between the equilibrium concentration and the quantity absorbed. Some examples of linear relations were also reported in the studies of Bird and Harris ${ }^{21}$ and Gonzales-Davilla et al..$^{22}$; and these isotherms were classified with the Nernst isotherm, that is $\{\mathrm{QD}\}=\mathrm{K}_{\mathrm{L}}[\mathrm{D}]$. The angular coefficient of

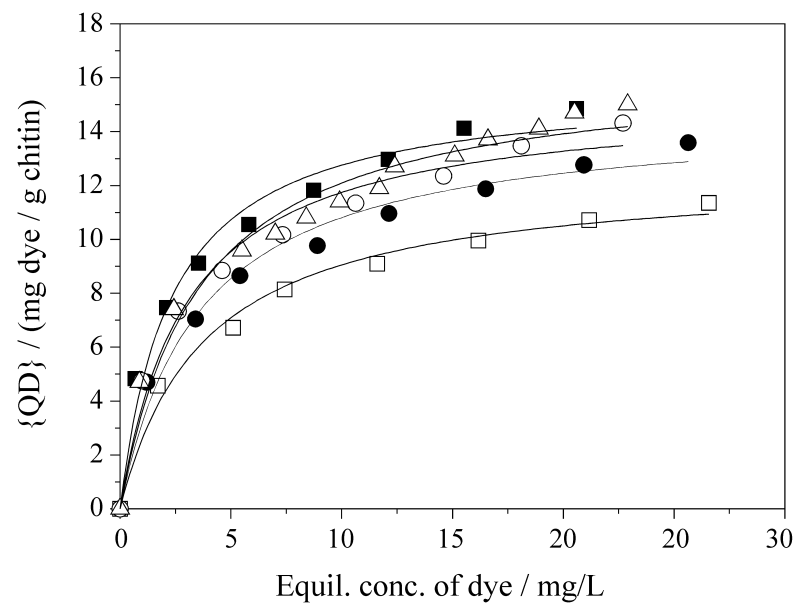

Figure 6. Adsorption of $\mathrm{OG}$ on chitin. $11.0 \pm 0.5^{\circ} \mathrm{C} . \Delta 25.0 \pm 0.5^{\circ} \mathrm{C}$. O $29.0 \pm 0.5{ }^{\circ} \mathrm{C} . \bullet 40.0 \pm 0.5^{\circ} \mathrm{C} . \square 60.0 \pm 0.5^{\circ} \mathrm{C}$. Acetate buffer $(0.10$ $\left.\mathrm{mol} \mathrm{L}{ }^{-1}\right), \mathrm{pH}=4.0$ and contact time of $60 \mathrm{~min}$.

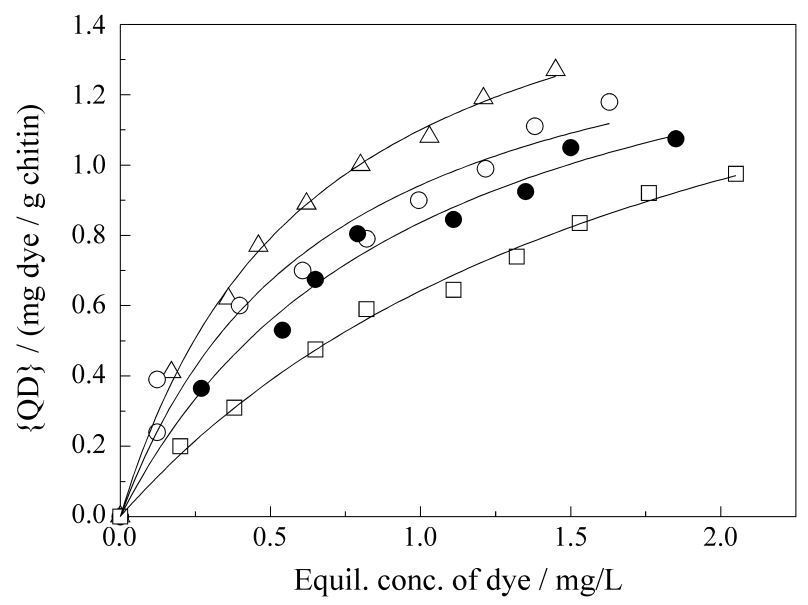

Figure 7. Adsorption of OIV on chitin. $\Delta 25.0 \pm 0.5^{\circ} \mathrm{C}$. O $35.0 \pm 0.5^{\circ} \mathrm{C}$. - $45.0 \pm 0.5^{\circ} \mathrm{C}$. $\square 53.0 \pm 0.5^{\circ} \mathrm{C}$. Acetate buffer $\left(0.10 \mathrm{~mol} \mathrm{~L}^{-1}\right), \mathrm{pH}=4.0$ and contact time of $60 \mathrm{~min}$. 


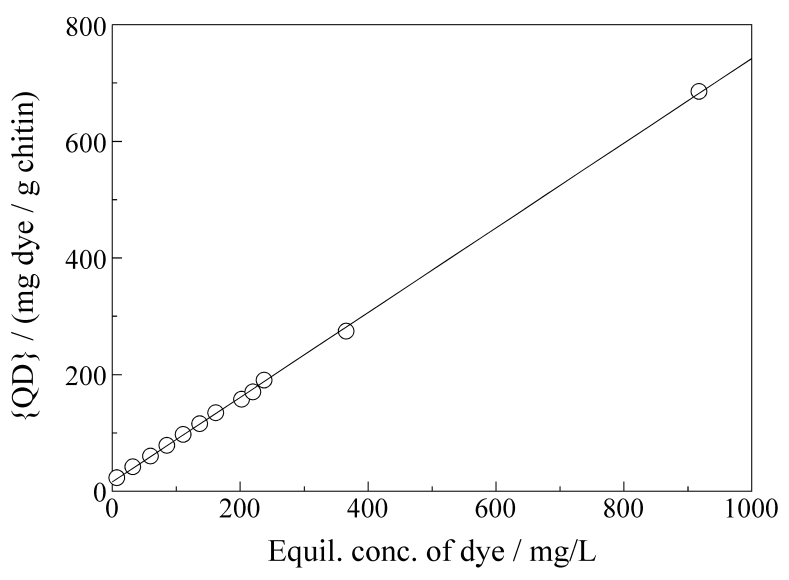

Figure 8. Adsorption of $\mathrm{XO}$ on chitin at $25.0 \pm 0.5^{\circ} \mathrm{C}$. Acetate buffer $\left(0.10 \mathrm{~mol} \mathrm{~L}^{-1}\right), \mathrm{pH}=4.0$ and contact time of $60 \mathrm{~min}$.

this isotherm $\left(\mathrm{K}_{\mathrm{L}}\right)$ corresponds to the ratio between the solubility of the dye in water and in the solid phase. In this case, the value of $\mathrm{K}_{\mathrm{L}}$ represents the partition coefficient of the Nernst equation. The partition coefficient of this dye between the two phases was $0.726 \mathrm{~L} \mathrm{mg}^{-1}$.

Langmuir adsorption parameters are determined by transforming the Langmuir Eq. 2 isotherm to a linear form. The isotherm can be made linear in at least four different ways. Depending on the linearization chosen shown in Table 1, different estimates are obtained for the values of the parameters. This occurs because, depending on the way the isotherm is linearized, the error distribution changes either for better or for worse ${ }^{18}$. However, the best transformation has been extensively reported in the biochemical literature where equations analogous to the Langmuir isotherm are important for the description of the binding sites for the drugs and enzyme catalysis. The best treatment is obtained by using the second equation in Table 1 , since this choice tends to minimize deviations from the fitted equation, resulting in the best error distribuition ${ }^{18}$.

Figures 9 and 10 illustrate the linearizations selected to calculate the adsorption parameters.

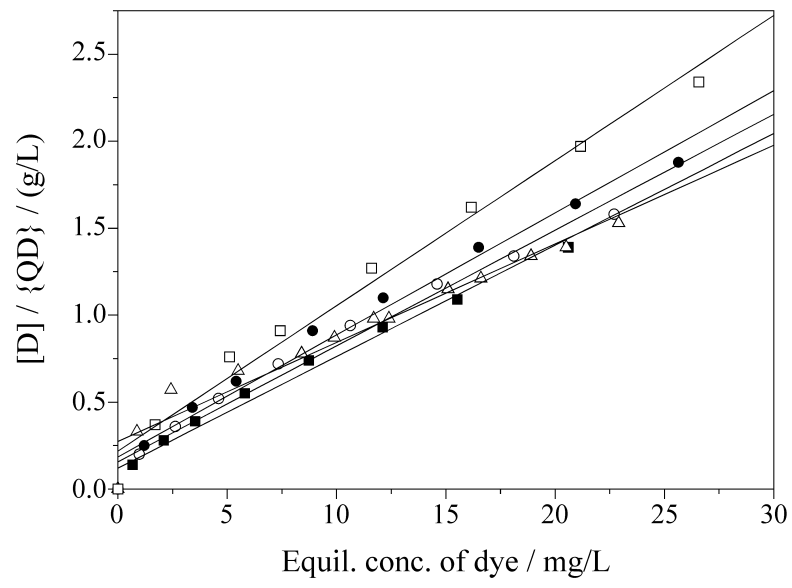

Figure 9. Linearization (2) of adsorption isotherm for OG. $11.0 \pm$ $0.5^{\circ} \mathrm{C} . \Delta 25.0 \pm 0.5^{\circ} \mathrm{C} . \mathrm{O} 29.0 \pm 0.5^{\circ} \mathrm{C} . \bullet 40.0 \pm 0.5^{\circ} \mathrm{C} . \square 60.0 \pm 0.5^{\circ} \mathrm{C}$.

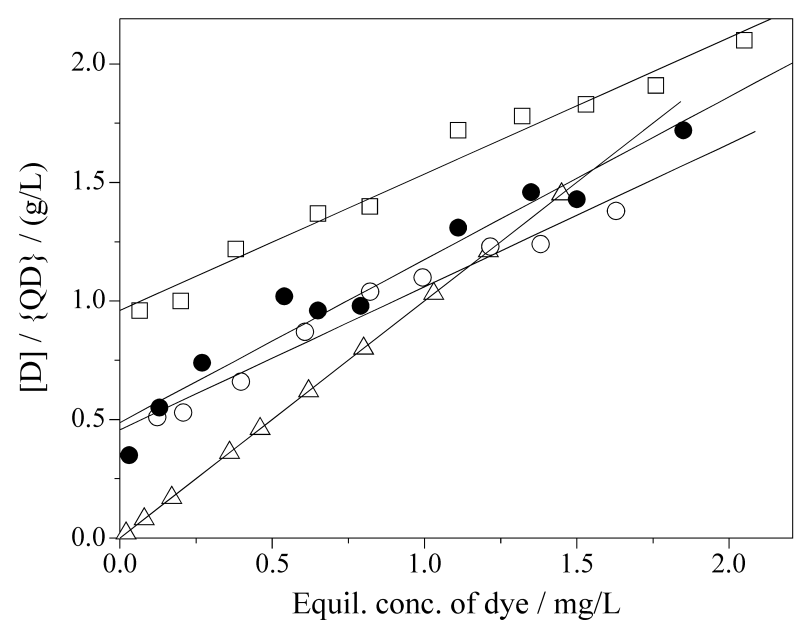

Figure 10. Linearization (2) of adsorption isotherm for OIV. $\Delta 25.0 \pm$ $0.5^{\circ} \mathrm{C} . \mathrm{O} 35.0 \pm 0.5^{\circ} \mathrm{C} . \bullet 45.0 \pm 0.5^{\circ} \mathrm{C} . \square 53.0 \pm 0.5^{\circ} \mathrm{C}$.

Table 2 illustrates the results of values of the adsorption parameters. In Eq. 2, $\mathrm{C}_{\mathrm{m}}$ represents the monolayer coverage in terms of $\mathrm{mg}$ dye/g chitin, and is related to the Langmuir equilibrium constant ${ }^{6}, \mathrm{~K}_{\mathrm{L}}$ by the equation:

Table 1. Linear transformations of the Langmuir isotherm.

\begin{tabular}{|c|c|c|}
\hline Linear Regression & Plot & Parameters \\
\hline \multirow[t]{2}{*}{ (1) $1 /\{\mathrm{QD}\}=1 / \mathrm{C}_{\mathrm{m}}+\left(1 / \mathrm{Kc}_{\mathrm{m}}[\mathrm{D}]\right)$} & $1 /\{\mathrm{QD}\}$ vs. $1 /[\mathrm{D}]$ & $\mathrm{K}=$ intercept/slope \\
\hline & & $\mathrm{C}_{\mathrm{m}}=1 /$ intercept \\
\hline \multirow[t]{2}{*}{ (2) $[\mathrm{D}] /\{\mathrm{QD}\}=1 / \mathrm{KC}_{\mathrm{m}}+\left([\mathrm{D}] / \mathrm{C}_{\mathrm{m}}\right)$} & {$[\mathrm{D}] /\{\mathrm{QD}\}$ vs. [D] } & $\mathrm{K}=$ slope $/$ intercept \\
\hline & & $C_{m}=1 /$ slope \\
\hline \multirow[t]{2}{*}{ (3) $\{\mathrm{QD}\}=\mathrm{C}_{\mathrm{m}}-(1 / \mathrm{K}) \cdot(\{\mathrm{QD}\} /[\mathrm{D}])$} & $\{\mathrm{QD}\}$ vs. $\{\mathrm{QD}\} /[\mathrm{D}]$ & $K=-1 /$ slope \\
\hline & & $\mathrm{C}_{\mathrm{m}}=$ intercept \\
\hline \multirow[t]{2}{*}{ (4) $\{\mathrm{QD}\} /[\mathrm{D}]=\mathrm{KC}_{\mathrm{m}}-\mathrm{K}\{\mathrm{QD}\}$} & $\{\mathrm{QD}\} /[\mathrm{D}] v s .\{\mathrm{QD}\}$ & $\mathrm{K}=-$ slope \\
\hline & & $\mathrm{C}_{\mathrm{m}}=$-intercept/slope \\
\hline
\end{tabular}




$$
\mathrm{K}_{\mathrm{L}}=\mathrm{C}_{\mathrm{m}} \mathrm{K}
$$

The effect of temperature on orange $\mathrm{G}$ and orange IV adsorption shows that the adsorption capacity decreases with the temperature. Orange $\mathrm{G}$ maximum adsorption decreases from 16.4 to $12.8 \mathrm{mg} \mathrm{g}^{-1}$. For orange IV, the capacity decreases from 1.64 to $1.50 \mathrm{mg} \mathrm{g}^{-1}$. This phenomenon is quite common ${ }^{6}$ and is caused by the increase in the desorption step when the temperature increases. The 10fold difference between the maximum quantity of adsorbed dye $\left(\mathrm{C}_{\mathrm{m}}\right)$ values for the dyes OG and OIV can be attributed to the interaction between the chitin chain and $\pi$-electron system of the orange $\mathrm{G}$, which is identified as van der Waals attraction. The extension of a planar dye molecule which can be oriented along one chitin chain probably determines this physical attraction. Also, hydrogen bond forces related to the hydroxyl group in the molecule can also contribute to this interaction.

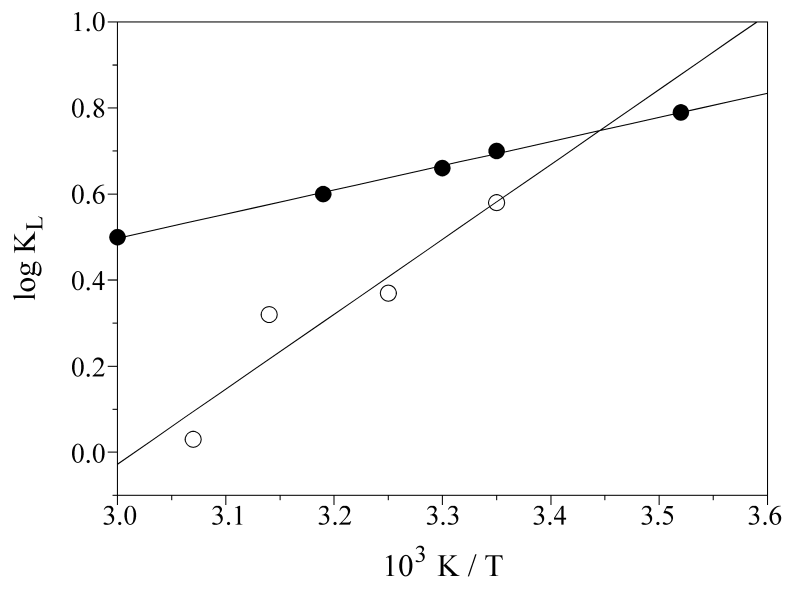

Figure 11. Log KL vs. 1/T: (•)OG, (O) OIV.
From the values of the constant $\mathrm{K}_{\mathrm{L}}$, the adsorption enthalpy was determined by plotting the $\log \mathrm{K}_{\mathrm{L}}$ vs. $1 / \mathrm{T}$ (Kelvin). The values of $\Delta \mathrm{H}$ of $-10.9 \mathrm{~kJ} \mathrm{~mol}^{-1}$ for orange $\mathrm{G}$ and $-28.9 \mathrm{~kJ} \mathrm{~mol}^{-1}$ for orange IV were determined by means of the angular coefficient in the graphs of Fig. 11. These values are in good agreement with those reported by McKay et al. ${ }^{6}$ for the adsorption of Acid Blue 25, Acid Blue 158 and Mordant Yellow on chitin. The negative values indicate that heat is released during the adsorption process, and the small values of $\Delta \mathrm{H}$ confirm an adsorption of a physical nature.

\section{Acknowledgments}

We thank CNPq, FNMA and FUNCITEC for financial support.

\section{References}

1. Muzzarelli, R.A.A. In Chitin; Pergamon Press: Oxford, England; 1977 p 8 and 11.

2. Mathur, N.K.; Narang, C.K. J. Chem. Educ. 1990, 67, 938.

3. Maghami, G.G.; Roberts, G.F.A. Makromol. Chem. 1988, 189, 239.

4. Yang, T.C.; Zall, R.R. Eng. Chem. Res.Div. 1984, 23, 168.

5. Giles, C.H.; Hassan A.S.A. J. Soc. Dyers Col. 1958, $74,846$.

6. McKay, G.; Blair, H.S.; Gardner, J.R. J. Appl. Polym. Sci. 1982, 27, 3043.

7. Adamson, W.A. Physical Chemistry of Surfaces; California, 1990, p 595.

8.Zollinger, H. In Color Chemistry: Syntheses, Properties, and Applicatios of Organic Dyes and Pigments; VCH Verlagsgesellschaft mbH, Weinheim, 1991.

Table 2. Parameter values of adsorption.

\begin{tabular}{lcccc}
\hline & & \multicolumn{3}{c}{ Langmuir constants } \\
\hline Dyes & $\mathrm{T}\left({ }^{\circ} \mathrm{C}\right)$ & $\mathrm{K}\left(\mathrm{dm}^{3} / \mathrm{mg}\right)$ & $\mathrm{Cm}(\mathrm{mg} / \mathrm{g})$ & $\mathrm{K}_{\mathrm{L}}\left(\mathrm{dm}{ }^{3} / \mathrm{g}\right)$ \\
\hline OG & 11 & $0.38 \pm 0.09$ & $16.40 \pm 0.60$ & $6.20 \pm 1.90$ \\
OG & 25 & $0.30 \pm 0.05$ & $16.40 \pm 0.80$ & $4.90 \pm 0.98$ \\
OG & 29 & $0.29 \pm 0.05$ & $15.90 \pm 0.70$ & $4.60 \pm 0.83$ \\
OG & 40 & $0.26 \pm 0.04$ & $15.20 \pm 0.60$ & $3.90 \pm 0.62$ \\
OG & 60 & $0.24 \pm 0.03$ & $12.80 \pm 0.30$ & $3.10 \pm 0.40$ \\
OIV & 25 & $1.90 \pm 0.10$ & $1.64 \pm 0.08$ & $3.12 \pm 0.15$ \\
OIV & 35 & $1.52 \pm 0.10$ & $1.54 \pm 0.09$ & $2.34 \pm 0.14$ \\
OIV & 45 & $1.06 \pm 0.11$ & $1.62 \pm 0.15$ & $1.72 \pm 0.17$ \\
OIV & 53 & $0.75 \pm 0.06$ & $1.50 \pm 0.13$ & $1.13 \pm 0.10$ \\
XO & 25 & - & - & $0.726 \pm 0.005$ \\
\hline
\end{tabular}


9. Nawar, S.S.; Doma, H.S. Sci. Total Environ. 1989, 79, 271.

10. Waters, B.D. Water. Pollut. Control. 1979, 78, 12.

11. Smith, K.T.; Brent; H.S. Am. Dyest. Rep. 1993, 82, 18.

12. Benszedits, S. Am. Dyest. Rep. 1980, 69, 37.

13. Nambooodri, C.G.; Perkins; W.K. Am. Dyest. Rep. 1994, 83, 17.

14. Hamza, A.; Hamoda, M.F. Industrial Waste Conference, Purdue University, Indiana, 1980, p 151.

15. Guoging, W.; Hengli, D.; Lin, C.; Lin; Z.N. Water Treat. 1990, 5, 463.
16. Fujita, T. Japan Patent, Chemical Abstract 1978, 7, 013, 599.

17. Broussignac, J. Chim. Ind. Gén. Chim. 1970, 99, 1241.

18. Kinniburgh, G.D. Environ. Sci. Technol. 1986, 20, 895.

19. Longhinotti, E.; Furlan, L.; Laranjeira, M.C.M.; Fávere, V.T. Química Nova 1996, 19, 221.

20. Furlan, L; Fávere, V.T.; Laranjeira, M.C.M. Polymer 1996, 37, 843.

21. Bird, C.L.; Harris, P. J. Soc. Dyers Col. 1957, 73, 199.

22. Gonzales-Davila, M.; Santana-Casiano; Millero, F.J. J. Colloid Interface Sci. 1990, 137, 102. 